\title{
Islam's Views on Sorcery and Black Magic
}

\author{
Mohammad Hashim Kamali*
}

Black magic is condemned in Islam but Muslim thinkers are not clear on how to deal with this superstitious holdover from an earlier age. Sorcery or witchcraft $(s i h r)$ is often equated with trickery aimed at conflating falsehood with the rational association of causes and effects.

Sorcery is difficult to define. Our knowledge of sihr and what is not within reach of our sense perception is also limited. The available information in the scriptural sources of Islam also falls short of elaboration on detail. Sihr may aim at inflicting harm on its object or at realising a benefit, and the sorcerer often resorts to irrational and impermissible means. Muslim scholars have differed on the reality of sihr.

The $\mathrm{Mu}$ 'tazilite rationalists held that sorcery is mere image-making and has no reality, and even considered one who believed in it as an infidel ( $k a \bar{f} f i r)$, claiming as authority a hadith stating that "one who resorts to sorcery truly associates other deities with God".

The majority of Muslim scholars have, however, concurred on the reality of sihr, its actual occurrence and its effects, as is also evident from the numerous references to it in the Qur'ān. Some have deemed sihr a branch of knowledge that subscribes to a methodology and set of rules. The Mu tazilites concurred, however, with the majority that God alone has the power to create body and soul, and natural endowments such as colour and taste ab initio. No sorcerer, jinn or Satan could genuinely transform, as Ibn Hazm (d. 1064) wrote, a human into an animal. Such would interfere in the order of God's creation.

While the 'ulam a' ' of all persuasions confirm the reality of sihr and the existence of invisible beings, the jinns and Satan, the one protective recourse against their harm, as Ibn Qayyim al-Jawziyyah (d. 1356) wrote, is faith in God and remembrance of Him such that fills the heart and mind of the believer. He then quotes this hadìth: "When the son of Adam prostrates and recites God's praise, Satan runs away and weeps saying 'the son of Adam was ordered to prostrate - he did and gained admission to Paradise; I was ordered to prostrate - I refused and fire became my refuge'." The implication is that prayer and supplication drive the evil forces away in suppression and defeat.

The Qur'ān views sihr as a pollutant of true belief (113:4) and speaks of it in reference to Pharaoh versus the Prophet Moses (7:116), the narratives of prophets David and Salomon, and in denunciation generally of those who teach and practise

* Professor Mohammad Hashim Kamali is the Chairman and CEO of IAIS Malaysia. An earlier version of this Viewpoint appeared on 8 November 2010 in The New Straits Times (Kuala Lumpur). 
it $(2: 102,21: 3)$, yet provides the assurance also that no harm will come to anyone unless God wills it (2:102). Whereas humans were created from earth, the jinns were created from fire (15:27). We cannot see the jinns but they can see us $(7: 27)$. They can travel with great speed and can appear to us in different forms.

Satan is a variety of jinn; they differ from the angels but share much of our predicament on this earth. They are endowed with intellect, feelings of love, jealousy and hate, and are bound by the laws of good and evil, accountability and worship. Some among them are pious and others transgress the divinely ordained limits. The hadith speaks of the evil gaze that can harm its victim: Ubay bin Ka'b narrated that he was present when a Bedouin came to the Prophet and asked him to help his brother who was unwell. The Prophet enquired and was informed that the sick man was possessed by spirits. On the Prophet's instruction, the man came and sat before him, who then recited a number of verses (31 in total) from different parts of the Qur'ān. Then the man rose and looked his normal self. Of interest here is that all the selected passages have a feature in common: affirmation of the oneness of God as the sole master of our destiny, His sovereignty over the universe, and belief in Him with total submission.

Sihr has an aspect in common with religion as both subscribe to belief in a supreme being, which is why it is difficult to define. Anthropologists maintain that superstition and magic predate religion and that the latter often came to curb the former. In the history of religion, when one religion triumphed over another, the latter was often called mere superstition and sorcery. Religion promotes moral and social objectives that inspire the approval of societies and generations whereas sihr aims at subjective benefits, and in its black variety at the infliction of harm. It is the object generally of repulsion and fear among sound-minded people. Black magic is objectionable as it harms people without their knowledge and opportunity to defend themselves. This kind of magic became a menace in medieval Europe often leading to the killing and burning alive of its perpetrators.

The further back one goes in the history of almost all societies, the greater one finds the hold of superstition among them. It is also true that scientific knowledge and true faith have a suppressing effect on sorcery, hence, the conclusion that sorcery is linked to superstition and ignorance. Primitive societies resorted to sorcery and magic to seek cures for disease. When religion and science fail to respond to the people's needs, superstition begins to take hold and fill their space. Advancements in medical science have also acted as a suppressor to a great extent, yet not entirely, as almost 50 per cent of known diseases to mankind have no known cure. 